famine and plague; but it was no doubt Enthoven's work on that census that led to his appointment as honorary superintendent of ethnography in Bombay, in which capacity he had charge of the ethnographical survey of the Presidency. This culminated in 1920 in the publication of his three volumes on "The Tribes and Castes of Bombay", a survey for which a small annual financial provision was made when the work started. This provision, however, was withdrawn in 1909 before the work was half done, and the task was carried to completion by the voluntary labours of Enthoven himself with such assistance as he could obtain without expenditure of funds. Crooke's "Tribes and Castes of the N.W. Provinces and Oudh", Risley's, Russell's, and Rose's similar volumes on Bengal, the Central Provinces, and the Punjab and North-West Frontier Province, and Thurston's "Castes and Tribes of Southern India", together with Enthoven's volumes on Bombay, all alike instigated in the first instance by Nesfield, Ibbetson and Risley, form the main corpus of information on Indian castes. But Enthoven, like Crooke and Thurston, went further and published in 1924 his volume on "The Folklore of Bombay", a very valuable continuation of the earlier work in the same field of Sir James Campbell, and a most important companion to the works of Crooke and Thurston. His interest in this aspect of Indian life had perhaps been kindled, or at any rate fed in him by an incident early in his career in which, as a junior magistrate, he was called upon to investigate the unnatural death of a girl as the result of an attempt to drive an evil spirit out of her by jumping on her and thrashing her.

In 1916 Enthoven got leave from India to take up a war-time appointment in the Board of Trade, where he became eventually controller of the department of import restrictions. He returned to India after the First World War, but retired in 1920 and became an underwriter at Lloyds. He was awarded the C.I.E. in 1920, and was also a Commander of the Order of Leopold II ; but it is for his work on Indian ethnography and folk-lore that he will be best remembered.

J. H. HutTon

\section{Dr. A. Lasnitzki}

Dr. Arthur Lasnitzki, who died suddenly at Birmingham on April 18 at the age of fifty-six, was born in Lauenburg, Germany. After completing his early education he studied medicine with special training in chemistry, physics and mathematics at the Universities of Berlin and Bonn. His predominant interests were in the scientific aspects of physiology and biochemistry.

During 1921-25 Lasnitzki worked at the Universities of Rostock and Berlin, where he carried out investigations on the biological action of hydrogen acceptors and the nature of heterogenic precipitins. His wide knowledge of chemistry and physics proved of great value in his studies on the surface tension of tissue fluids and the absorptive capacity of hydrophyllic colloids. $\mathrm{He}$ also elaborated a manometric method for the determination of lipase in body fluids and tissues.

During the past twenty-five years he devoted his great abilities to the problem of cancer and the intricate nature of the cancer cell. From 1926 until 1933 he worked as head of the Biochemical Laboratory of the Cancer Research Institute, University of Berlin, where he carried out and directed studies on the metabolism and the influence of electrolytes on adult, embryonic and tumour tissues. In 1933, due to the Nazi oppression, Lasnitzki was dismissed from his post but found refuge at the University of Manchester, where he spent the next five years, working untiringly and in difficult circumstances. In collaboration with A. K. Brewer, of Washington, he was among the earliest to investigate the occurrence of isotopic and radioactive elements in tumour and normal tissues, in particular the significance of the shift of the isotopic potassium in neoplastic growth.

For the past fourteen years Dr. Lasnitzki had worked at the Medical School, Birmingham, continuing his biochemical studies and examining some aspects of carcinogenesis, particularly the histological changes in the lymph nodes of animals induced by carcinogenic hydrocarbons and extracts of cancer tissues. Much of this work is still unpublished, and some he had been unable to complete.

Dr. Lasnitzki always extended a warm-hearted generosity towards colleagues and friends who sought his help or advice. He was keenly interested in meetings of scientific societies and found great satisfaction in exchanging ideas with others on these occasions. $\mathrm{He}$ had a sensitive disposition, and occupied his mind with science almost to the exclusion of other sides of life. It was his high intellectual integrity which made him suffer intensely when he witnessed the decline of principles and standards he held dear. Though in failing health for several months, he had been drawing together results of his researches only a few hours before his death, with the meticulous care which characterized all his work.

$\mathrm{He}$ is survived by his widow, who has collaborated with him in a number of his researches.

\section{Sir Algernon Aspinall, K.C.M.G., C.B.E.}

Sir ALgernon Aspinall, secretary of the West India Committee for forty years, until his retirement in 1938, and of the Imperial College of Tropical Agriculture, British West Indies, from its foundation until 1940, recently died at the age of eighty. Himself not a man of science-he was called to the Bar in 1897-Sir Algernon was one of those who did much to promote the cause of science in its application to the problems of tropical agriculture. His work in connexion with West Indian agriculture, in particular with sugar and cocoa, and in relation to the founding and management of the affairs of the Imperial College of Tropical Agriculture - the recognized centre for postgraduate training for the Colonial Agricultural Service - will long be remembered with gratitude and respect by those who undertook the actual work on the spot. His keen personal interest in, and appreciation of, their efforts and the warmth of his welcome on their return to London were palpable factors in building up the tradition of sound scientific endeavour in the tropics. Sir Algernon is well known as the author of several guide and other books on the West Indies. These reflect the man . they are learned, friendly, witty and urbane.

WE regret to announce the following deaths :

Prof. H. A. D. Neville, C.B.E., emeritus professor of agricultural chemistry in the University of Reading, on June 17, aged seventy-one.

Sir Lindsay Scott, K.B.E., president during 1946 50 of the Prehistoric Society, on June 17, aged fifty-nine. 